\section{SOI: $1.1 /$ TAS DOI: $10.15863 /$ TAS International Scientific Journal Theoretical \& Applied Science}

p-ISSN: 2308-4944 (print) e-ISSN: 2409-0085 (online)

Year: $2018 \quad$ Issue: 02 Volume: 58

Published: $12.02 .2018 \quad \underline{\text { http://T-Science.org }}$
Kylychbek Azimovich Kurbanbayev Candidate of Philosophy Science, Osh State University, ossu.oms@gmail.com

Ainura Kulmatovna Nurbaeva Researcher, Osh State University, Kyrgyzstan ossu.oms@gmail.com

SECTION 30: Philosophy.

\title{
THE ESSENCE AND SPECIFICITY OF ART
}

Abstract: In this article explores the essence and specificity of art. As a form of public consciousness, art reflects the environment in the form of images that act on the feelings of people, and the article analyzes the specifics of art in the modern world. As the author points out, the problem of the social role of art, its influence on a person, and the formation of a personality is of particular practical importance.

Key words: arts, fiction, painting, graphics, sculpture, architecture, image, reality, consciousness, aesthetics.

Language: Russian

Citation: Kurbanbayev KA, Nurbaeva AK (2018) THE ESSENCE AND SPECIFICITY OF ART. ISJ Theoretical \& Applied Science, 02 (58): 24-27.

Soi: http://s-o-i.org/1.1/TAS-02-58-7 Doi: crossef https://dx.doi.org/10.15863/TAS.2018.02.58.7

УДК: 7.011

\section{СУЩНОСТЬ И СПЕЦИФИКА ИСКУССТВА}

Аннотация: В данной статье исследуется сущность и специфика искусства. Как форма общественного сознания искусство отражает окружающую среду в форме образов, которые действуют на чувства людей, а также в статье анализируется специифика искусства в современном мире. Как отмечает автор, особую практическую значимость сейчас приобретает проблема сочиальной роли искусства, ее влияния на человека, на формирование личности.

Ключевые слова: искусства, художественная литература, живопись, графика, скульптура, архитектура, образ, реальность, сознание, эстетика.

\section{Introduction}

Искусство являлось предметом философских изысканий с античных времен, существует немало различных теорий искусства, но нельзя сказать, что его сущность, специфика, социальная значимость поняты до конца, что не осталось ни- каких дискуссионных вопросов в его понимании. Этот феномен человеческой жизни слишком сложен и многогранен, чтобы можно было в определенный момент создать его полную и окончательную теорию. Поэтому изучение проблем теории искусства сохраняет свою актуальность.

\section{Materials and Methods}

Искусство - отрасль человеческой деятельности, стремящаяся к удовлетворению одной из духовных потребностей человека, а именно любви к прекрасному. Искусство подразделяется на тоническое: поэзия, музыка и на образное: архитектура, скульптура, живопись $[2$, с. 325]. Вполне очевидно, что подобное определение искусства не является философским. Во-первых, поэзия и музыка тоже представляют собой образное видение мира, но образы эти другие они вербальны, а не визуальны, как в живописи. Во-вторых, философский подход подразумевает разностороннее, глубинное рассмотрение любого явления, и не по- тому, что философия так хочет, а потому что мир, окружающий нас, не линеен, не плосок, не прост. Такая сегодняшняя очевидность мира когда-то была обнаружена как сенсация и вызвала среди ученых смятение, кризис мировоззрения, отразившись в науке как «кризис физики». И это был не частный кризис в научном, позитивном знании, а кризис в глобальном понимании мира, кризис в философии. Вообще, грань между физикой и философией очень хрупка, а может быть ее и вовсе не существует. Не случайно, греческие философы на «заре» философии предпочитали называть себя не философами, а физиками. И, думается, греки демонстрировали не наивность мышления, а некую чистоту мысли, 
свободную от условностей зрелого мира, отягощенного разумными построениями, позволяющую отражать его богаче.

Мир, окружающий нас, не просто разносторонен, он противоречив. В нем причудливо сочетаются противоположности. Еще Гераклит Эфесский обратил внимание на то, что часто враждебное находится в согласии, противоположное - совпадает. Свет не может существовать без тьмы, день - без ночи, смерть без жизни. «Один и тот же путь вверх и вниз», «У винта путь прямой и кривой», «У окружности начало и конец совпадают». Отсюда он выводит идею относительности всех ценностей: для рыб морская вода - чистая, свиньи купаются в грязи, птицы моются в пыли, ослы предпочитают солому золоту.

Прекраснейшая обезьяна отвратительна по сравнению с человеческим родом, болезнь делает сладостным здоровье, голод сообщает приятность сытости, а тяжкий труд дает вкусить отдых [3, с. 35]. Поэтому перед философией стоит особая задача - отразить мир во всей его сложности и многообразии, а значит, целостности, что существенно отличает философское знание от научного, разрывающего мир на части, и сближает, скорее, с искусством. Но стоит ли изучать мир по частям? Несомненно стоит, чтобы достичь детального, конкретного знания. Но мир не существует по частям. И это уже прерогатива философии.

«В широком смысле под искусством понимается всякая творческая созидательная деятельность человека. Именно в этом смысле употребляют его древние греки. В переводе с греческого искусство означает «знание», «творение», «сознание». Все, что связано с деятельностью человека и с продуктами этой деятельности, относится к сфере poiesis человеческой сфере, созданной в противоположность physis - сфере природной, т. е. не созданной им. В узком смысле под искусством понимаются процессы и результаты художественного творчества в его различных формах - живопись, музыка, поэзия и т. д.» [3, с. 25].

Важным критерием художественности содержания искусства является жизненная реальность, истина. Познание действительности при помощи различных форм искусства способствует расширению знаний человека и формирует мировоззрение личности. Результатом воздействия искусства на человека является формирование мировоззрения, морали, a также эстетических вкусов. Поэтому для современного человека важно социально преобразующее значение искусства, его действенная роль как могучего способа влияния на умы и чувства индивида в условиях глобализации.

В чувственно - конкретной форме искусства отражаются самые важные проблемы человеческого бытия. Социальная роль искусства заключается в том, чтобы быть специфическим средством воздействия на идеологическое познание жизни. Особенность искусства заключается в ценностном, конкретно - чувственном отражении объективной реальности и в результате этого в системном влиянии в духовой мир личности. Л.Н. Столович утверждает, что «искусство в его художественной специфике и ценности - это явление, созданное «по законам красоты» для отражения действительности в ее эстетическом своеобразии, для выражения эстетического сознания человека и для эстетического воздействия на людей. Искусство возникло для того, чтобы формировать, воспитывать, направлять эстетический вкус человека и общества. Л.Н. Столович выделяет 14 функций искусства и подчеркивает, что «основания функция искусства» - эта функция эстетического воздействия на личность человека. Эстетическое - «системообразующее начало различных функциональных значений искусства» [9, с.19.20].

Из всего многообразия эстетических объектов самым важным является духовная жизнь человека. Поэтому потребность в эстетичности, гармонии поведения является необходимым компонентом личной культуры. Прекрасное во взаимоотношениях человека с человеком - это стремление заботиться друг о друге, помогать друг другу. Внешняя красота должна быть выражением внутреннего духовного богатства. В структуре эстетических потребностей одно из ведущих мест занимает потребность в искусстве. М. Горький утверждал, что цель искусства - преувеличивать хорошее, чтобы оно стало еще лучшее, преувеличивать плохое, уродующее человека, чтобы оно возбуждало ненависть со всякому злу. Рассматривая искусство как сложное явление, необходимо выделить его полифункциональность, многоплановость воздействия на личность. Познавательная, воспитательная, коммуникативная, ориентационная, гедонистическая и другие функции искусства реализуются при помощи образного отражения объективной реальности. Музыка, живопись, литература, театр, кино и другие виды искусства обладают уникальным, образно-воспитательным воздействием на личность.

Природа искусства в диалектическом единстве всех его функций и особенностей, однако это не снимает спор о специфике искусства. И.Астахов 
указывал, что "отрицание эстетической сущности искусства означает отрицание художественной формы и содержания" [4, с.124]. Встает вопрос: представляет ли искусство по форме специфическое эстетическое явление? Как соотносится художественное и эстетическое?.

Само понятие эстетического было введено в XVIII веке А. Баумгартеном, под эстетическим он понимал "Чувственное познание, помогающее постичь красоту действительности", т.е. у Баумгартена суть эстетического - красота, которая воспринимается и познается человеческими чувствами.

Под эстетическим, как известно, всегда понимают красоту, или прекрасное. Во всяком случае, все признают, что "прекрасное" есть основная эстетическая категория. Бесспорно, искусство включает в себя эстетический момент. Однако, сразу становится очевидно, что искусство отражает не только красоту, "красивое не есть искусство", указывал Н. Чернышевский [12, c.89].

Л. Столович определяет эстетическое как "чувственно-образное и идейно-эмоциональное, духовно утверждающее человека в действительности" [10, с.43]. Во-первых, он отожествляет чувственное и эстетическое. Если, например, человек испытывает эмоцию страха, то что здесь эстетического? И не всякий образ, сопровождающийся эмоцией, является эстетическим. Так, у человека, испытывающего жажду, образ стакана с водой, несомненно, вызовет чувство радости, но природа этой радости не эстетическая, а всякая ли эмоция "утверждает человека в действительности"? Страх, плач не только не утверждает, не дает человеку самоутвердиться, но и может унизить его. Что здесь эстетического?

Как известно, чувства делятся на интеллектуальные, социальные и эстетические. Эстетическое чувство - это чувство красоты, прекрасного. Красота - одна из универсальных форм бытия материального мира в сознании человека. Известно, "эстетическая деятельность шире художественной" [10, с. 147]. Эстетическое и художественное разные понятия. Поэтому художественная форма не есть чисто эстетическое явление. Сущность художественной формы вытекает из её назначения служить выражением содержания искусства, а содержание произведения искусства несет не только эстетическое, но и нравственное, идеологическое и т.д. Поэтому непринятие эстетического в качестве сущности искусства, совсем не означает, что художественная форма и содержание теряют смысл. Таким образом, эстетическое не исчерпывает сущности искусства.
Э. Шарипова подчеркивает, что "репутация руководителя как специалист в принятии своих решений и оценка деятельности сотрудников, независимо от объективности. Для того, чтобы достичь до уровня лидера политических, научных, технических, этических, социальных и психологических факторов необходимо развивать свои навыки и искусства управления"[13, с. 12].

\section{Conclusion}

Искусство понятие сложное и многогранное, основные концепции искусства познавательная, эстетическая, воспитательная, исходившие из функций искусства (познавательной, эстетической, воспитательной), свели по сути смысл искусства к одной из его особенностей. Искусство- это форма отражения и осознания действительности. Хотя искусство - это прежде всего искусственно созданный человеком мир, но этот "новый мир" есть образ реального мира, т.е. человек творит "новую реальность" из существующей действительности. Искусство обусловлено природой и теми общественными отношениями, в которых находится человек. Искусство зависит от характера деятельности людей, от степени освоения природы, от уровня производства. "Искусство, - как полагал Ж. Гюйо, - это функция общественного организма". Отсюда главным родовым признаком искусства, в числе других признаков, присущих понятию "искусство", есть признак формы общественного сознания. Этот признак отличает искусство от всего, что не есть форма общественного сознания. Но известно, что понятие определяется еще и видовым отличаем (спецификой), т.е. тем, что выделяет искусство как форму общественного сознания от других форм общественного сознания: религии, политики, морали, правосознания, науки.

Искусство рассматривает явления и предметы не ради их простого отображения, а чтобы возбудить эмоциональное состояние души. Bce продукты, т.е. произведения искусства, предназначены для восприятия органами чувств: зрением и слухом, именно посредством их передается содержание и смысл произведения искусства. Непосредственная область действия искусства - это чувства, а через чувства и душу человека искусство влияет на личность в целом. Искусство пробуждает чувства, но это особые чувства (радость встречи с другом, например, это тоже чувство, но искусство здесь ни при чем), в искусстве чувства возбуждаются не реальными фактами, а искусственно переданными художником, писателем, музыкантом. Особенности художественной эмоции выделил С. Раппопорт. Он пишет: "Художественная эмоция всегда несет социально-историческое содер- 


\begin{tabular}{|c|c|c|c|c|c|c|}
\hline Impact Factor: & $\begin{array}{l}\text { ISRA (India) } \\
\text { ISI (Dubai, UAE } \\
\text { GIF (Australia) } \\
\text { JIF }\end{array}$ & $\begin{array}{l}=1.344 \\
=\mathbf{0 . 8 2 9} \\
=0.564 \\
=1.500\end{array}$ & $\begin{array}{l}\text { SIS (USA) } \\
\text { PИНЦ (Russia) } \\
\text { ESJI (KZ) } \\
\text { SJIF (Morocco) }\end{array}$ & $\begin{array}{l}=0.912 \\
=0.207 \\
=4.102 \\
=2.031\end{array}$ & $\begin{array}{l}\text { ICV (Poland) } \\
\text { PIF (India) } \\
\text { IBI (India) }\end{array}$ & $\begin{array}{l}=6.630 \\
=1.940 \\
=4.260\end{array}$ \\
\hline
\end{tabular}

жание, общее для исходных переживаний многих людей, художественная эмоция всегда положительна, даже когда в обыденной жизни она и негативна, отрицательные эмоции приносят положительный эффект".
Таким образом, искусство не возникает там, где есть даже самое искреннее чувство, необходимы разум, творчество, воображение. Но без эмоций искусство теряет свою сущность, свое предназначение.

\section{References:}

1. Andreev A.L. (1980) Mesto iskusstva v poznanii mira. -M.Politizdat. - $253 \mathrm{p}$.

2. Andreev A.L. (1981) Hudozhestvennyj obraz i gnoseologicheskaja specifika iskusstva. -M.: Nauka. - 193 p.

3. Anohin P.K. (1984) Jemocii // Psihologija jemocij. -M.: Moskovskij universitet. - p. 172177.

4. Astahov I.B. (1971) Jestetika. -M.:Moskovskij rabochij. - 439 p.

5. Golopurov V. (1984) Jesteticheskie normy i kirgizskoe iskusstvo. -Frunze: Kyrgyzstan. -111 p.

6. Zdravomyslov A.G. (1986) Potrebnosti. Interesy. Cennosti.-M.: Politizdat. - 223 p.

7. Kozubaev O.K. (1995) Jeticheskaja mysl' v retrospektive. -Bishkek: Kyrg.s.-h.in-t im. K.I.Skrjabina. - 159 p.
8. Mahnicheva K. (2001) Kul'turnaja norma kak social'no-psihologicheskaja problema.

Bishkek: Ilim. - 40 p.

9. Stolovich L.N. (1985) Zhizn'-tvorchestvochelovek. -M.Politizdat. - 415 p.

10. Stolovich L.N. (1978) Filosofija krasoty. M.:Politizdat. - $118 \mathrm{p}$.

11. Stolovich L.N. (1983) Jesteticheskaja i hudozhestvennaja cennost': sushhnost', specifika, sootnoshenie. -M.. - p. 19.-20

12. Chernyshevskij N.G. (1950) Izbrannye filosofskie sochinenija. T. 1-3. M.:Gospolitizdat.

13. Sharipova Je.K. (2008) Social'nye normy kak ob'ekt filosofskih issledovanij: Aftoref. dis. dra filos. nauk. -Bishkek. $-29 \mathrm{p}$. 